\title{
Can arbuscular mycorrhizal fungi ameliorate the adverse effects of deficit irrigation on tall fescue (Festuca arundinacea Schreb.)?
}

Sayyed Mohammad Ehsan Mahdavi ${ }^{1}$, Hassan Salehi ${ }^{1 *}$, Mehdi Zarei ${ }^{2}$

${ }^{1}$ Department of Horticultural Science, School of Agriculture, Shiraz University, Shiraz, Iran. ${ }^{2}$ Department of Soil Science, School of Agriculture, Shiraz University, Shiraz, Iran.

*Corresponding author: hsalehi@shirazu.ac.ir

\begin{abstract}
With increasing concerns over global warming, the shortage of water supplies has turned to be a disputable problem in the world. Drought stress is one of the most prevalent abiotic stresses that affect turfgrass growth and quality in landscapes of arid or semi-arid regions. Among the common cool-season turfgrasses, tall fescue can tolerate drought more than other grasses. Fungal bio-fertilizers, especially Arbuscular Mycorrhizal Fungi (AMFs) are able to alleviate the harmful effects of abiotic stresses in the plant. This study was conducted in two consecutive years, 2014 and 2015, to evaluate how two types of AMFs (Funneliformis mosseae and Rhizophagus irregularis) would affect the growth characteristics of two cultivars ('H-d' and 'J-r') of tall fescue (Festuca arundinacea Schreb.) in the greenhouse and field conditions. Three irrigation intervals were applied, i.e. 7, 14 or 21-days. Results showed that by irrigating less frequently, the visual quality of turfgrass decreased, and there were reductions in the fresh weight, chlorophyll content, and relative water content. However, there were increases in the amount of phosphorus in the shoots, root colonization, compatible solutes (proline and glycine betaine) and antioxidant enzymes (superoxide dismutase and peroxidase). However, these changes were more pronounced in turfgrasses that were treated with AMFs. Qualitative and quantitative characteristics were substantially more promising in the greenhouse than in the field. This is the first report on the morpho-physiological and biochemical responses of tall fescue to AMFs. Results of this investigation could inspire further such works on other turfgrasses, given that the inoculation of turfgrasses with AMFs is a new approach with uncharted potentials that aims at reducing water consumption in the landscape environment.
\end{abstract}

Keywords: Arbuscular mycorrhizal, fungi, drought tolerance, enzyme activity, osmoprotectant, phosphorus, turfgrass 


\section{Introduction}

The beauty and elegance of a landscape can partly depend on the pleasant green color of turfgrass since it comprises the main background of the landscape. The scarcity of water can influentially limit the irrigation of turfgrass and thus would reduce turfgrass quality, especially in arid and semi-arid zones. Therefore, water management is the main concern with regard to the management of turfgrass (McCann and Huang, 2007). During the past few decades, bio-fertilizers such as AMFs, make plants tolerant against abiotic stresses under unsuitable climatic conditions, have become the most applicable materials in nutritional programs and have drawn the attention of many researchers (Rai, 2006).

AMFs constitute the most popular mutual symbiosis that can occur between plant roots and the rhizosphere microorganisms (Smith and Read, 2008). Symbiosis thereby affects some morphological, anatomical and cell aspects of the plant via AMFs. These can promote the absorption of nutritional mineral elements and consequently the plants' growth and water uptake efficiency. AMFs can cause to increase photosynthesis and water absorption and further contribute to the production of osmoregulators. They cause phosphates in the rhizosphere to become more absorbable and induce stress genes that counter stressful conditions. In addition to being known as bio-fertilizer, AMFs can serve as bio-control agents or bio-productive agents and thereby improve the plant's tolerance to biotic and abiotic stresses as when plant hormones would act accordingly (e.g., Jasmonic acid (JA), salicylic acid (SA), ethylene, auxin, gibberellin (GA), cytokinin (CK), Abscisic acid (ABA) and Strigolactone (SL)) (Garg and Chandel, 2010; López-Ráez, 2015; Pozo et al., 2015). Moreover, AMFs can reduce the harmful effects of abiotic factors, which is to some extent known as the bioremediation of contaminated soils and the bio-monitoring of soil quality (Cornejo et al., 2017; Jeffries et al., 2003).

The most tolerant to heat and drought among the coolseason turfgrasses is the tall fescue (Festuca arundinacea Schreb.). Its exceptional drought tolerance results from its extensive root system that allows the plant to maintain the natural physiological state via its drought avoidance mechanisms (Fry and Huang, 2004). In spite of reports demonstrate the positive effects of AMFs on the physiological function of turfgrasses, there have been few studies on how AMFs affect qualitative and quantitative characteristics of turfgrasses (Nikbakht and Pessarakli, 2014). To the best of our knowledge, this research is the first to investigate how AMFs affect the tall fescue growth under drought condition.

\section{Materials and Methods}

This experiment was conducted under greenhouse conditions and also in the field environment (Bajgah) close to the Department of Horticultural Sciences, School of Agriculture, Shiraz University, Shiraz, Iran $\left(52^{\circ} 32^{\prime} \mathrm{E}\right.$ and $29^{\circ} 36^{\prime} \mathrm{N}, 1810 \mathrm{~m}$ asl). The research was done in 2 consecutive years from 2014 to 2015 . The tillers of two cultivars of tall fescue were used. These cultivars were namely 'J-r' as drought-tolerant and 'H-d' as less tolerant to drought. Biochemical and physical characteristics of water and soil of the Bajgah region, Fars province were measured. Data are shown in Table 1. The plastic pots used in the experiment measured 25 liters in volume, $36 \mathrm{~cm}$ in height and 33 $\mathrm{cm}$ in diameter. Field capacity (FC) and permanent wilting point (PWP) of each pot were calculated by pressure plate apparatus and the results were joined to determine irrigation intervals (IIs). Average temperatures of the day and night were $30 \pm 3$ and $24 \pm 3{ }^{\circ} \mathrm{C}$, 
respectively, and the relative humidity was $50 \pm 5 \%$ in the greenhouse. Table 2 further elaborates on data pertaining to the climate. Maximum and minimum average of monthly temperatures in July and March were 25.76 and $8.16{ }^{\circ} \mathrm{C}$, respectively. The average temperatures and relative humidity during the experiment were $17.3{ }^{\circ} \mathrm{C}$ and $35.2 \%$, respectively.

Table 1. Physico-biochemical properties of the soil and chemical analysis of the irrigation water used in the experiment

\begin{tabular}{|c|c|c|c|c|c|}
\hline \multicolumn{4}{|c|}{ Soil } & \multicolumn{2}{|c|}{ Water } \\
\hline \multicolumn{2}{|c|}{ Physical property } & \multicolumn{2}{|c|}{ Biochemical property } & \multicolumn{2}{|c|}{ Chemical analysis } \\
\hline \multirow{2}{*}{ Clay (\%) } & \multirow{2}{*}{59.28} & $\mathrm{pH}$ & 7.76 & $\mathrm{pH}$ & 7.1 \\
\hline & & $\mathrm{EC}\left(\mathrm{dS} \mathrm{m}^{-1}\right)$ & 0.76 & $\mathrm{EC}\left(\mathrm{dS} \mathrm{m} \mathrm{m}^{-1}\right)$ & 0.49 \\
\hline \multirow[t]{2}{*}{ Silt (\%) } & \multirow[t]{2}{*}{40.00} & $\begin{array}{c}\text { Organic matter } \\
\qquad \%)\end{array}$ & 1.2 & $\mathrm{HCO}_{3}^{-}\left(\mathrm{mg} \mathrm{l}^{-1}\right)$ & 1.12 \\
\hline & & $\mathrm{N}\left(\mathrm{mg} \mathrm{kg}^{-1}\right)$ & 6.55 & $\mathrm{CO}_{3}^{-}\left(\mathrm{mg} \mathrm{l}^{-1}\right)$ & 0 \\
\hline \multirow{2}{*}{ Texture } & \multirow{2}{*}{ Clay } & $\mathrm{P}\left(\mathrm{mg} \mathrm{kg}^{-1}\right)$ & 25 & $\mathrm{P}_{2} \mathrm{O}_{4}^{+}\left(\mathrm{mg} \mathrm{l}^{-1}\right)$ & 0.01 \\
\hline & & $\mathrm{K}\left(\mathrm{mg} \mathrm{kg}^{-1}\right)$ & 600 & $\mathrm{NO}_{2}\left(\mathrm{mg} \mathrm{l}^{-1}\right)$ & 0.03 \\
\hline \multirow{3}{*}{$\begin{array}{c}\text { Field capacity } \\
\qquad(\%)\end{array}$} & \multirow{3}{*}{24.3} & $\begin{array}{c}\text { Microbial } \\
\text { respiration } \\
\left(\mathrm{mg} \mathrm{CO}_{2} \mathrm{~kg}^{-1}\right)\end{array}$ & 2.8 & $\mathrm{NO}_{3}^{-}\left(\mathrm{mg} \mathrm{l}^{-1}\right)$ & 7.4 \\
\hline & & $\begin{array}{l}\text { Microbial biomass } \\
\qquad\left(\mathrm{mg} \mathrm{C} \mathrm{kg}^{-1}\right)\end{array}$ & 12.1 & $\mathrm{Cl}^{-}\left(\mathrm{mg} \mathrm{l}^{-1}\right)$ & 43.6 \\
\hline & & $\begin{array}{c}\text { Most probable } \\
\left.\text { number (MPN g }{ }^{-1}\right)\end{array}$ & $1.1 \times 10^{4}$ & $\mathrm{Mg}^{2+}\left(\mathrm{mg} \mathrm{l}^{-1}\right)$ & 2.2 \\
\hline
\end{tabular}


Table 2. Meteorological data of experimental region

\begin{tabular}{|c|c|c|c|c|c|c|c|c|c|c|}
\hline \multirow[t]{2}{*}{ Year } & \multirow[t]{2}{*}{ Month } & \multicolumn{3}{|c|}{$\begin{array}{l}\text { Average monthly temperature } \\
\qquad\left({ }^{\circ} \mathrm{C}\right)\end{array}$} & \multirow{2}{*}{$\begin{array}{l}\text { Sunny } \\
\text { hours }\end{array}$} & \multirow{2}{*}{$\begin{array}{l}\text { Evaporation (mm } \\
\left.24 \mathrm{~h}^{-1}\right)\end{array}$} & \multirow{2}{*}{$\begin{array}{c}\text { Rainfall } \\
(\mathrm{mm})\end{array}$} & \multicolumn{3}{|c|}{$\begin{array}{c}\text { Average relative humidity } \\
\text { (\%) }\end{array}$} \\
\hline & & Mean & Max & Min & & & & Mean & $\operatorname{Max}$ & Min \\
\hline \multirow{5}{*}{ 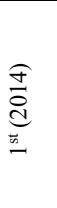 } & March & 8.80 & 16.82 & 0.69 & 7.62 & 8.15 & 17.0 & 44.06 & 70.32 & 17.81 \\
\hline & April & 12.07 & 20.44 & 3.71 & 8.51 & 5.39 & 41.5 & 41.95 & 67.98 & 15.91 \\
\hline & May & 16.70 & 26.15 & 7.24 & 9.04 & 7.52 & 1.0 & 39.34 & 64.29 & 14.39 \\
\hline & June & 22.15 & 33.07 & 11.23 & 13.73 & 10.33 & 0.0 & 29.52 & 47.48 & 11.55 \\
\hline & July & 25.62 & 35.99 & 15.23 & 10.66 & 11.08 & 0.0 & 26.92 & 40.65 & 13.19 \\
\hline \multirow{5}{*}{ 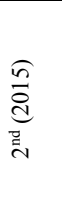 } & March & 7.52 & 14.05 & 0.70 & 7.06 & 3.84 & 45.0 & 43.47 & 66.31 & 20.62 \\
\hline & April & 13.64 & 20.55 & 6.74 & 7.50 & 5.62 & 39.5 & 43.10 & 67.31 & 19.00 \\
\hline & May & 17.62 & 27.59 & 7.66 & 9.54 & 6.59 & 10.0 & 34.56 & 56.39 & 17.63 \\
\hline & June & 22.98 & 33.46 & 12.50 & 10.67 & 9.08 & 0.0 & 24.65 & 37.71 & 11.58 \\
\hline & July & 25.90 & 35.85 & 15.95 & 10.85 & 11.18 & 0.0 & 24.48 & 13.55 & 25.90 \\
\hline
\end{tabular}

Source: Meteorological Station, School of Agriculture, Shiraz University.

\subsection{Microorganisms}

To evaluate the effects of 2 species of Fm and Ri, fungi were obtained from the Department of Soil Science, Shiraz University, Shiraz, Iran. These fungi were isolated from the Anguran Mine, Zanjan, Iran, during a research by Zarei et al. (2008a). Fifty g of sand-based inoculum of mycorrhizal fungi (containing spore numbers of 12-10 $\mathrm{g}^{-1}$ substrate and RC of $85-85 \%$, respectively) were incorporated in the ground with AM sorghum's (Sorghum bicolor (L.) Moench) roots. The mixture was prepared through the trap culture of roots at the depth of $5 \mathrm{~cm}$ in the soil and was added to each pot. These were mixed thoroughly with the soil. For the control group, the pots were used containing an equal amount of sterilized sandbased inocula (Zarei et al., 2008b).

\subsection{Treatments and experimental setup}

To evaluate the effects of treatments, the greenhouse experiment was conducted in the factorial arrangement as a completely randomized design with 3 replications. The field experiment was based on a randomized com- plete block design with 3 replications. For appropriate growth and adaption, tillers were irrigated for 5 weeks to an extent that allowed the soil moisture to be at FC. The II treatments began to be performed when plants were well established. The II lasted for 12 weeks. Treatments were 2 cultivars of tall fescue (' $\mathrm{H}-\mathrm{d}$ ' and 'J-r'), there were 3 IIs (7, 14 and 21-days) and 3 fungi levels (the control group, Funneliformis mosseae and Rhizophagus irregularis). weeks. Treatments were 2 cultivars of tall fescue ('H-d' and 'J-r'), there were 3 IIs (7, 14 and 21-days) and 3 fungi levels (the control group, Funneliformis mosseae and Rhizophagus irregularis).

\subsection{Measurements}

2.3.1. Total fresh weight (FW) and visual quality (VQ)

At the end of the experiments, plants were harvested and separated into their root, clippings and verdure. Each part was weighed and total FW was calculated by summing their weights. Turfgrass VQ was measured according to shoot color, uniformity, and density, weediness and speed 
of establishment by being rated from 0 to 9 , in which the highest quality acquired the highest score (9).

\subsubsection{Leaf chlorophyll (Chl) and relative water con-} tent (RWC)

To determine Chl content, the samples were extracted with $80 \%$ acetone. Chl was measured by using the method of spectrophotometry (Esmaili and Salehi, 2012), using the following formula 1 :

$\mathrm{mg} \mathrm{Chl} / \mathrm{g} \mathrm{f.w.}=[(20.2(\mathrm{OD} 645 \mathrm{~nm})+(8.02(\mathrm{OD} 663 \mathrm{~nm})] \times \mathrm{V} / \mathrm{f} . \mathrm{w} . \times 1000$

where: OD is the optical density, $\mathrm{V}$ is the final solution volume in $\mathrm{ml}$ and f.w. is the plant tissue's freshweight in $\mathrm{mg}$.

RWC was measured with González and GonzálezVilar (2001) method. For this reason, $0.2 \mathrm{~g}$ fresh leaf was weighed and placed in $50 \mathrm{ml}$ distilled water for $4 \mathrm{~h}$, and then the turgid leaves were weighed. Then, leaf samples were oven dried for calculating the dry weight at $70{ }^{\circ} \mathrm{C}$ for $48 \mathrm{~h}$. The RWC was determined by the following formula 2 :

$$
\operatorname{RWC}(\%)=(\text { f.w. }- \text { d.w. }) /(\text { s.w. }- \text { d.w. }) \times 100
$$

where: f.w. is fresh-weight, d.w. is dry-weight and s.w. is the saturated-weight.

\subsubsection{Compatible solute content}

Determination of proline (Pro) content was done by the method described by Bates et al. (1973). Briefly, $0.5 \mathrm{~g}$ dried leaf sample was shaken and homogenized with sulfo-salicylic acid. Thereafter, the extract was exposed to react chemically with glacial acid and acid-ninhydrin for $1 \mathrm{~h}$ at $100{ }^{\circ} \mathrm{C}$ in a Bain-marie. Then, samples were extracted with toluene and the samples' absorbance were measured at $520 \mathrm{~nm}$.

The concentration of glycine betaine (GB) was determined using the method of Grieve and Grattan (1983).
Briefly, $0.5 \mathrm{~g}$ dried leaf was homogenized with deionized water. Samples were mixed with sulfuric acid and potassium iodide-iodine (KI-I2), and were then centrifuged. To extract GB, the peridotite crystals that had formed were dissolved in 1, 2-Dichloroethane (DCA) and then sample absorbance was measured at $365 \mathrm{~nm}$.

\subsubsection{Enzyme assay}

Superoxide dismutase (SOD) activity was determined according to the method described by Beauchamp and Fridovich (1971). The measurement was based on the ability of the SOD enzyme in preventing the reduction of nitro blue tetrazolium photochemical by the $\mathrm{O}_{2} \bullet$ - radical as the most prominent reactive oxygen species (ROS) in the presence of riboflavin. Sample absorbance was measured at $560 \mathrm{~nm}$.

Peroxidase (POX) activity in leaves of experimental plants was measured by method of Chance and Maehly (1955) with minor modifications. The enzyme activity measurement was based on the peroxidase enzyme and $\mathrm{H}_{2} \mathrm{O}_{2}$ radical ability. The absorbance of extract was read every 10 seconds for $1 \mathrm{~min}$ at $470 \mathrm{~nm}$.

\subsubsection{Phosphorus $(\mathrm{P})$ content and root colonization} (RC)

Determination of $\mathrm{P}$ concentration was done by the colorimetric assay (Watanabe and Olsen, 1965). To calculate $\mathrm{P}$ content, the standard curve was drawn for 0.1 to $1 \mathrm{mg} / 1 \mathrm{P}$ at $890 \mathrm{~nm}$.

The method was used to determine RC described by Kormanik and McGraw (1982). Briefly, $0.5 \mathrm{~g}$ root was placed in a test tube containing potassium hydroxide (KOH) $8 \%$ for 24 hours. Then, the content of the tube was removed and roots were placed in hydrochloric acid (HCL) 2\% for 15 minutes. Then, the acid was removed, and a colored solution (acid 
fuchsine) was added. These were stored at room temperature for 24 hours. In both cases, the dye solution comprised lactic acid, glycine and water with a ratio of 14:1:1. Fungal organs including arbuscule, hyphae, vesicles and spores were visible under the stereomicroscope.

\subsubsection{Recovery period}

When the field experiment had finished, measurements were taken to compare the recovery rate of plants under fungi treatments with plants of the control pots. For this purpose, plants that were treated under 21-day II were cut back by shoot clippings, and then pots were irrigated to maintain soil moisture at field capacity for 5 weeks.

\section{Results}

The two consecutive years of collecting data had significant differences with each other based on the Bartlett test. Therefore, the two years of results are presented separately.

\subsection{Visual quality}

For the greenhouse experiment, signs of yellowing and wilting (leaf rolling in tall fescue) where observed a month after applying drought stress. The VQ decreased significantly with increasing II in both cultivars. The best VQ was obtained in 'H-d', the 7-day II and in both fungal treatments. The best results were found in the interaction between ' $\mathrm{H}-\mathrm{d}$ ', the 7-day II and the Ri fungal treatment, while the worst VQ was observed in pots without fungi, the 21-day II for the 'J-r'.

Table 3. Main effects and interactions between different treatments on visual quality (0-9) and total fresh weight (g)

\begin{tabular}{|c|c|c|c|c|c|c|c|c|c|c|c|c|c|c|c|c|}
\hline \multirow[b]{2}{*}{ Cultivars } & \multirow[b]{2}{*}{ Fungi } & \multirow{2}{*}{$\begin{array}{l}\text { Irrigation } \\
\text { intervals }\end{array}$} & \multicolumn{3}{|c|}{ Interactions VQ } & \multicolumn{3}{|c|}{ Interactions total FW } & \multirow{2}{*}{$\begin{array}{l}\text { Main } \\
\text { effects }\end{array}$} & \multirow[b]{2}{*}{ TRTs } & \multicolumn{3}{|c|}{ VQ } & \multicolumn{3}{|c|}{ Total FW } \\
\hline & & & In & Out $1^{\text {st }}$ & Out $2^{\text {nd }}$ & In & Out $1^{\text {st }}$ & Out $2^{\text {nd }}$ & & & In & Out $1^{\text {st }}$ & Out $2^{\text {nd }}$ & In & Out $1^{\text {st }}$ & Out $2^{\text {nd }}$ \\
\hline \multirow{9}{*}{ 'H-d' } & \multirow{3}{*}{ Control } & 7 & $6.66 \mathrm{~cd} \dagger$ & $6.00 \mathrm{bc}$ & $6.33 \mathrm{bc}$ & $378.29 \mathrm{e}$ & $154.95 \mathrm{e}$ & $147.10 \mathrm{f}$ & \multirow{4}{*}{ 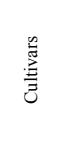 } & \multirow[t]{2}{*}{$\mathrm{Hd}$} & \multirow[t]{2}{*}{$6.29 \mathrm{~A}$} & \multirow[t]{2}{*}{$4.29 \mathrm{~B}$} & \multirow[t]{2}{*}{$4.77 \mathrm{~B}$} & \multirow{2}{*}{$330.24 \mathrm{~B}$} & \multirow{2}{*}{$119.82 \mathrm{~B}$} & \multirow[t]{2}{*}{$122.76 \mathrm{~B}$} \\
\hline & & 14 & $5.33 \mathrm{ef}$ & $3.33 \mathrm{hi}$ & $3.66 \mathrm{f}$ & $316.35 \mathrm{f}$ & $87.82 \mathrm{~h}$ & $81.27 \mathrm{ij}$ & & & & & & & & \\
\hline & & 21 & $3.66 \mathrm{gh}$ & 0.331 & $1.00 \mathrm{i}$ & $168.53 \mathrm{~h}$ & $32.86 \mathrm{k}$ & 48.571 & & \multirow[t]{2}{*}{$\mathrm{Jr}$} & \multirow[t]{2}{*}{$5.51 \mathrm{~B}$} & \multirow[t]{2}{*}{$4.85 \mathrm{~A}$} & \multirow[t]{2}{*}{$5.22 \mathrm{~A}$} & \multirow[t]{2}{*}{$396.92 \mathrm{~A}$} & \multirow[t]{2}{*}{$137.29 \mathrm{~A}$} & \multirow[t]{2}{*}{$139.95 \mathrm{~A}$} \\
\hline & \multirow{3}{*}{$\begin{array}{c}\text { Rhizophagus } \\
\text { irregularis }\end{array}$} & 7 & $8.33 \mathrm{a}$ & $7.33 \mathrm{a}$ & $7.00 \mathrm{ab}$ & $470.62 \mathrm{c}$ & $176.07 \mathrm{~cd}$ & $179.32 \mathrm{de}$ & & & & & & & & \\
\hline & & 14 & $7.33 \mathrm{a}-\mathrm{c}$ & $5.00 \mathrm{~d}-\mathrm{f}$ & $6.33 \mathrm{~cd}$ & $395.50 \mathrm{e}$ & 167.30de & $160.95 \mathrm{ef}$ & \multirow{8}{*}{ 照 } & \multirow{3}{*}{ CTL } & & & & & & \\
\hline & & 21 & $5.33 \mathrm{ef}$ & $2.00 \mathrm{jk}$ & $2.66 \mathrm{gh}$ & $193.39 \mathrm{gh}$ & $55.58 \mathrm{ij}$ & $74.98 \mathrm{jk}$ & & & \multirow[t]{2}{*}{$4.88 \mathrm{~B}$} & $3.50 \mathrm{C}$ & $3.94 \mathrm{C}$ & $325.34 \mathrm{~B}$ & $101.63 \mathrm{~B}$ & $105.43 \mathrm{~B}$ \\
\hline & \multirow{3}{*}{$\begin{array}{c}\text { Funneliformis } \\
\text { mosseae }\end{array}$} & 7 & $8.00 \mathrm{ab}$ & $7.33 \mathrm{a}$ & $7.33 \mathrm{a}$ & $486.79 \mathrm{c}$ & $204.63 \mathrm{~b}$ & $200.34 \mathrm{bc}$ & & & & & & & & \\
\hline & & 14 & $6.33 \mathrm{c}-\mathrm{e}$ & $4.66 \mathrm{ef}$ & $5.66 \mathrm{c}-\mathrm{e}$ & $386.54 \mathrm{e}$ & $107.31 \mathrm{f}$ & $117.01 \mathrm{~g}$ & & $\mathrm{Ri}$ & $6.44 \mathrm{~A}$ & $4.94 \mathrm{~B}$ & $5.33 \mathrm{~B}$ & $376.87 \mathrm{~A}$ & $143.74 \mathrm{~A}$ & $145.04 \mathrm{~A}$ \\
\hline & & 21 & $5.66 \mathrm{~d}-\mathrm{f}$ & $2.66 \mathrm{ij}$ & $3.33 \mathrm{fg}$ & $176.14 \mathrm{~h}$ & $91.90 \mathrm{gh}$ & $95.29 \mathrm{hi}$ & & & & & & & & \\
\hline & & 7 & $6.33 \mathrm{c}-\mathrm{e}$ & $5.33 \mathrm{c}-\mathrm{e}$ & $5.33 \mathrm{de}$ & $483.43 \mathrm{c}$ & $184.00 \mathrm{c}$ & $186.66 \mathrm{~cd}$ & & $\mathrm{Fm}$ & $6.38 \mathrm{~A}$ & $5.27 \mathrm{~A}$ & $5.72 \mathrm{~A}$ & $388.53 \mathrm{~A}$ & $140.29 \mathrm{~A}$ & $143.59 \mathrm{~A}$ \\
\hline & Control & 14 & $4.66 \mathrm{fg}$ & $4.33 \mathrm{fg}$ & $5.00 \mathrm{e}$ & $392.77 \mathrm{e}$ & $103.66 \mathrm{fg}$ & $110.95 \mathrm{gh}$ & & & & & & & & \\
\hline & & 21 & $2.66 \mathrm{~h}$ & $1.66 \mathrm{k}$ & $2.33 \mathrm{~h}$ & $212.66 \mathrm{~g}$ & $46.53 \mathrm{i}-\mathrm{k}$ & $58.01 \mathrm{kl}$ & & & & & & & & \\
\hline & Rhizophagus & 7 & $7.33 \mathrm{a}-\mathrm{c}$ & $6.66 \mathrm{ab}$ & $6.33 \mathrm{bc}$ & $581.71 \mathrm{~b}$ & $260.95 \mathrm{a}$ & $258 . .55 \mathrm{a}$ & & 7 & $7.27 \mathrm{~A}$ & $6.66 \mathrm{~A}$ & $6.66 \mathrm{~A}$ & $50853 \mathrm{~A}$ & $198.91 \mathrm{~A}$ & $196.45 \mathrm{~A}$ \\
\hline 'J-r' & irregularis & 14 & $6.66 \mathrm{~cd}$ & $5.66 \mathrm{~cd}$ & $6.00 \mathrm{~cd}$ & $409.10 \mathrm{de}$ & $159.64 \mathrm{e}$ & $144.59 \mathrm{f}$ & & & & & & & & \\
\hline & & 21 & $3.66 \mathrm{gh}$ & $3.00 \mathrm{hi}$ & $4.00 \mathrm{f}$ & $210.88 \mathrm{~g}$ & $42.89 \mathrm{jk}$ & 51.861 & 总 & 14 & $6.00 \mathrm{~B}$ & $4.83 \mathrm{~B}$ & $5.44 \mathrm{~B}$ & $389.31 \mathrm{~B}$ & $132.08 \mathrm{~B}$ & $130.37 \mathrm{~B}$ \\
\hline & Funneliformis & 7 & $7.00 \mathrm{bc}$ & $7.33 \mathrm{a}$ & $7.66 \mathrm{a}$ & $650.32 \mathrm{a}$ & $212.84 \mathrm{jk}$ & $206.74 \mathrm{~b}$ & 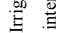 & & & & & & & \\
\hline & mosseae & 14 & $5.66 \mathrm{~d}-\mathrm{f}$ & $6.00 \mathrm{bc}$ & $6.33 \mathrm{bc}$ & $435.61 d$ & $166.75 \mathrm{de}$ & 167.46de & & 21 & $4.44 \mathrm{C}$ & $2.22 \mathrm{C}$ & $288 \mathrm{C}$ & $192.90 \mathrm{C}$ & $54.68 \mathrm{C}$ & $67.23 \mathrm{C}$ \\
\hline & & 21 & $5.66 \mathrm{~d}-\mathrm{f}$ & $3.66 \mathrm{gh}$ & $4.00 \mathrm{f}$ & $195.79 \mathrm{gh}$ & $58.34 \mathrm{i}$ & $74.70 \mathrm{jk}$ & & & & & & & & \\
\hline
\end{tabular}

$\dagger$ Means having different letters (capitals for the main effects and lower cases for interactions) are significantly different at $5 \%$ level by LSD test. *(VQ): visual quality; (FW): fresh weight; (In): greenhouse condition; (Out $\left.1^{\text {st }}\right)$ : field environment in the $1^{\text {st }}$ year; (Out $2^{\text {nd) }}$ : field environment in the $2^{\text {nd }}$ year; (TRTs): treatments; (CTL): control; (Ri): Rhizophagus irregularis; (Fm): Funneliformis mosseae. 
For the field experiment, the main effects of treatments were investigated. The best quality was observed in 'J-r' during both years, but the remarkable result was of the best quality in ' $\mathrm{H}$-d' in combination with the 7-day II and also another remarkable result was for the 'J-r' in combination with the 14-day II and the 21-day II. In both years, the Fm caused the best VQ in the field experiment. Interaction between both cultivars and the 7-day II showed the best result. However, it should be noted that the 14-day II also exhibited an acceptable quality. Generally, the VQ decreased as the II increased in tall fescue. But, this reduction was more intangible when Fm was applied than when Ri was (Table 3).

\subsection{Chlorophyll content}

The Chl content in ' $\mathrm{H}$-d' was more than the content in 'J-r' among plants in the greenhouse. Among fungi levels of treatment, the highest $\mathrm{Chl}$ content was found in the Fm treatment, while the control had the lowest $\mathrm{Chl}$ content. The $\mathrm{Chl}$ decreased as the II increased. By comparing the different interactions, the highest $\mathrm{Chl}$ content was found in the 'H-d' treated with the 7-day II by the Fm fungus, while the lowest $\mathrm{Chl}$ content was observed in the ' $\mathrm{J}$-r' treated with the 21-day II and by no fungus, concerning the greenhouse environment.

Similar to the greenhouse, the field environment provided for the ' $\mathrm{H}$-d' to have more $\mathrm{Chl}$ content during both years. Among fungi treatment levels, the best performance was observed by the Fm for the first year of the experiment, while the Ri caused the best performance in the second year. As expected, the Chl content decreased by increasing the II factor under field condition. In the first year of the experiment, the highest level of Chl was observed in the ' $\mathrm{H}-\mathrm{d}$ ' treated with the Fm fungus and by the 7-day II, and in the second year, the highest was observed in the 'J-r' treated with the Ri fungus and by the 7-day II. The second highest Chl content was belonged to the 'H-d' treated with the Fm fungus and by the 7-day II in the second year (Table 4).

\subsection{Relative water content}

In the greenhouse experiment, RWC decreased as the II increased. The ' $\mathrm{J}-\mathrm{r}$ ' is considered as a tolerant cultivar with high RWC. Both fungi treatments maintained the RWC.

For both years, there appeared no significant difference between the two cultivars in the field environment, but the 'J-r' had more RWC than 'H-d'. Both fungi, especially Fm, had the greatest positive effect on the RWC. The interaction between different treatments resulted in the outcome that the ' $\mathrm{H}$-d' is the more susceptible cultivar to drought and had the highest RWC in combination with the Fm fungus and the 7-day II. The lowest RWC was observed in the same cultivar by the 21-day II and with no fungal treatment (Table 4). 
Table 4. Main effects and interactions between different treatments on chlorophyll content (mg/gr F.W.) and shoot relative water content $(\%)$

\begin{tabular}{|c|c|c|c|c|c|c|c|c|c|c|c|c|c|c|c|c|}
\hline \multirow{2}{*}{ Cultivars } & \multirow{2}{*}{ Fungi } & \multirow{2}{*}{$\begin{array}{l}\text { Irrigation } \\
\text { intervals }\end{array}$} & \multicolumn{3}{|c|}{ Interactions Chl } & \multicolumn{3}{|c|}{ Interactions RWC } & \multirow{2}{*}{$\begin{array}{l}\text { Main } \\
\text { effects }\end{array}$} & \multirow{2}{*}{ TRTs } & \multicolumn{3}{|c|}{ Chl } & \multicolumn{3}{|c|}{ RWC } \\
\hline & & & In & Out $1^{\text {st }}$ & Out $2^{\text {nd }}$ & In & Out $1^{\text {st }}$ & Out $2^{\text {nd }}$ & & & In & Out $1^{\text {st }}$ & Out $2^{\text {nd }}$ & In & Out $1^{\text {st }}$ & Out $2^{\text {nd }}$ \\
\hline \multirow{9}{*}{ 'H-d' } & \multirow{3}{*}{ Control } & 7 & $1.06 \mathrm{~cd} \dagger$ & $0.83 \mathrm{~d}$ & $0.57 \mathrm{f}-\mathrm{h}$ & $83.23 \mathrm{~cd}$ & $67.70 \mathrm{~d}$ & $70.59 \mathrm{~d}$ & \multirow{4}{*}{ 苞 } & \multirow{2}{*}{$\mathrm{Hd}$} & \multirow{2}{*}{$0.86 \mathrm{~A}$} & \multirow{2}{*}{$0.74 \mathrm{~A}$} & \multirow{2}{*}{$0.70 \mathrm{~B}$} & \multirow{2}{*}{$76.09 \mathrm{~B}$} & \multirow{2}{*}{$55.88 \mathrm{~A}$} & \multirow{2}{*}{$58.74 \mathrm{~A}$} \\
\hline & & 14 & $0.85 \mathrm{~h}$ & $0.63 \mathrm{~g}$ & $0.68 \mathrm{ef}$ & $75.06 \mathrm{e}$ & $53.16 \mathrm{fg}$ & $55.96 \mathrm{fg}$ & & & & & & & & \\
\hline & & 21 & $0.72 \mathrm{k}$ & $0.50 \mathrm{~h}$ & $0.48 \mathrm{~h}$ & $58.10 \mathrm{~g}$ & $32.99 \mathrm{k}$ & $34.73 \mathrm{k}$ & & \multirow[t]{2}{*}{$\mathrm{Jr}$} & \multirow[t]{2}{*}{$0.87 \mathrm{~B}$} & \multirow[t]{2}{*}{$0.60 \mathrm{~B}$} & \multirow[t]{2}{*}{$0.79 \mathrm{~A}$} & \multirow[t]{2}{*}{$79.93 \mathrm{~A}$} & \multirow[t]{2}{*}{$57.70 \mathrm{~A}$} & \multirow[t]{2}{*}{$60.58 \mathrm{~A}$} \\
\hline & \multirow{3}{*}{$\begin{array}{c}\text { Rhizophagus } \\
\text { irregularis }\end{array}$} & 7 & $1.12 \mathrm{ab}$ & $0.92 \mathrm{ab}$ & $0.86 \mathrm{c}$ & $86.56 \mathrm{bc}$ & $73.94 \mathrm{~b}-\mathrm{d}$ & $77.83 \mathrm{bc}$ & & & & & & & & \\
\hline & & 14 & $0.98 \mathrm{e}$ & $0.71 \mathrm{f}$ & $0.71 \mathrm{de}$ & $84.43 \mathrm{~cd}$ & $57.53 \mathrm{ef}$ & $60.55 \mathrm{ef}$ & \multirow{8}{*}{ 客 } & \multirow{3}{*}{ CTL } & & & & & & \\
\hline & & 21 & $0.82 \mathrm{hi}$ & $0.61 \mathrm{~g}$ & $0.56 \mathrm{f}-\mathrm{h}$ & $62.36 \mathrm{fg}$ & $39.99 \mathrm{ij}$ & $42.09 \mathrm{j}$ & & & \multirow[t]{2}{*}{$0.83 \mathrm{C}$} & $0.59 \mathrm{C}$ & $0.66 \mathrm{C}$ & $75.52 \mathrm{~B}$ & $51.13 \mathrm{~B}$ & $53.70 \mathrm{~B}$ \\
\hline & \multirow{3}{*}{$\begin{array}{c}\text { Funneliformis } \\
\text { mosseae }\end{array}$} & 7 & $1.15 \mathrm{a}$ & $0.95 \mathrm{a}$ & $1.13 \mathrm{~b}$ & $84.36 \mathrm{~cd}$ & $84.43 \mathrm{a}$ & $88.86 \mathrm{a}$ & & & & & & & & \\
\hline & & 14 & $1.04 \mathrm{~d}$ & $0.83 \mathrm{~d}$ & $0.75 \mathrm{c}-\mathrm{e}$ & $82.91 \mathrm{~cd}$ & $53.11 \mathrm{fg}$ & $55.90 \mathrm{fg}$ & & $\mathrm{Ri}$ & $0.93 \mathrm{~B}$ & $0.68 \mathrm{~B}$ & $0.84 \mathrm{~A}$ & $78.87 \mathrm{~A}$ & $58.85 \mathrm{~A}$ & $61.88 \mathrm{~A}$ \\
\hline & & 21 & $0.92 \mathrm{fg}$ & $0.71 \mathrm{f}$ & $0.56 \mathrm{f}-\mathrm{h}$ & $67.50 \mathrm{f}$ & $40.05 \mathrm{ij}$ & $42.15 \mathrm{ij}$ & & & & & & & & \\
\hline & & 7 & $1.03 \mathrm{~d}$ & $0.77 \mathrm{e}$ & $0.88 \mathrm{c}$ & $91.69 \mathrm{ab}$ & $70.82 \mathrm{~cd}$ & $74.54 \mathrm{~cd}$ & & $\mathrm{Fm}$ & $0.99 \mathrm{~A}$ & $0.75 \mathrm{~A}$ & $0.74 \mathrm{~B}$ & $79.64 \mathrm{~A}$ & $60.39 \mathrm{~A}$ & $63.39 \mathrm{~A}$ \\
\hline & Control & 14 & $0.74 \mathrm{jk}$ & $0.50 \mathrm{~h}$ & $0.69 \mathrm{ef}$ & 79.24de & $47.62 \mathrm{gh}$ & $50.12 \mathrm{gh}$ & & & & & & & & \\
\hline & & 21 & 0.591 & $0.29 \mathrm{j}$ & $0.67 \mathrm{ef}$ & $65.82 \mathrm{f}$ & $34.47 \mathrm{jk}$ & $36.28 \mathrm{jk}$ & & & & & & & & \\
\hline & Rhizophaqus & 7 & $1.07 \mathrm{~b}-\mathrm{d}$ & $0.85 \mathrm{~cd}$ & $1.38 \mathrm{a}$ & $94.80 \mathrm{a}$ & $78.43 \mathrm{ab}$ & $81.22 \mathrm{~b}$ & & 7 & $1.09 \mathrm{~A}$ & $0.87 \mathrm{~A}$ & $0.91 \mathrm{~A}$ & $89.11 \mathrm{~A}$ & $75.21 \mathrm{~A}$ & $78.83 \mathrm{~A}$ \\
\hline 'J-r' & invegularis & 14 & $0.87 \mathrm{gh}$ & $0.62 \mathrm{~g}$ & $0.67 \mathrm{ef}$ & $82.18 \mathrm{~cd}$ & $57.21 \mathrm{ef}$ & $61.22 \mathrm{ef}$ & & & & & & (1) & & \\
\hline & & 21 & $0.72 \mathrm{k}$ & $0.41 \mathrm{i}$ & $0.84 \mathrm{~cd}$ & $62.92 \mathrm{fg}$ & $45.98 \mathrm{hi}$ & $48.40 \mathrm{hi}$ & $\stackrel{5}{\frac{5}{ \pm त}}$ & 14 & $0.90 \mathrm{~B}$ & $0.65 \mathrm{~B}$ & $0.72 \mathrm{~B}$ & $81.61 \mathrm{~B}$ & $54.80 \mathrm{~B}$ & $57.68 \mathrm{~B}$ \\
\hline & Funneliformis & 7 & $1.11 \mathrm{a}-\mathrm{c}$ & $0.88 \mathrm{bc}$ & $0.63 \mathrm{e}-\mathrm{g}$ & $93.70 \mathrm{a}$ & $75.96 \mathrm{bc}$ & $79.95 \mathrm{bc}$ & $\stackrel{.00}{E}$ & & & & & & & \\
\hline & mosseae & 14 & $0.93 \mathrm{ef}$ & $0.64 \mathrm{~g}$ & $0.83 \mathrm{~cd}$ & $85.85 \mathrm{c}$ & $60.15 \mathrm{e}$ & $62.32 \mathrm{e}$ & & 21 & $0.76 \mathrm{C}$ & $0.50 \mathrm{C}$ & $0.60 \mathrm{C}$ & $63.31 \mathrm{C}$ & $40.35 \mathrm{C}$ & $42.47 \mathrm{C}$ \\
\hline & & 21 & $0.79 \mathrm{ij}$ & $0.48 \mathrm{~h}$ & $0.50 \mathrm{gh}$ & $63.16 \mathrm{fg}$ & 48.61gh & $51.14 \mathrm{gh}$ & & & & & & & & \\
\hline
\end{tabular}

$†$ Means having different letters (capitals for the main effects and lower cases for interactions) are significantly different at 5\% level by LSD test. * (Chl): chlorophyll; (RWC): relative water content; (In): greenhouse condition; (Out $1^{\text {st) }}$ : field environment in the $1^{\text {st }}$ year; (Out $2^{\text {nd }}$ ): field environment in the $2^{\text {nd }}$ year; (TRTs): treatments; (CTL): control; (Ri): Rhizophagus irregularis; (Fm): Funneliformis mosseae.

Based on the obtained results, the 'J-r' exhibited the highest Pro content in the field environment. The Fm fungus caused the best effect on the Pro content of tall fescue in both years. The lowest Pro was observed in the control plants. Pro content increased parallel to the increase in II for the field environment. The lowest Pro content was observed in the interaction between ' $\mathrm{H}$ d', no fungus and the 7-day II treatments. The highest content was shown in the 'J-r', Fm and the 7-day II treatments (Table 5).

\subsection{Glycine betaine}

The highest GB content was observed in the ' $J$-r' inside the greenhouse. In total, the fungal treatment had the highest GB content compared to the control. Drought stress increased the GB content. The highest r', Ri and the 21-day II in the greenhouse environment.The 'J-r' had the highest GB content in the field environment.
Similar to the greenhouse experiment, the control had the lowest GB content and the Ri had the highest level of GB. In the first year, by increasing the II to 14-day interval, the GB increased and thereafter exhibited a downward trend when treated by the 21-day II. The interaction between treatments showed that in the first year, the 'J-r' that was treated with the Fm fungus and the 14-day II had the highest GB content under field condition. A high content also observed in the case of 'J-r' being treated with Ri and the 21-day II. On the other hand, the lowest GB content was observed in the 'H-d' that was treated with no fungus by the 21-day II. Results of the second year showed that the 'J-r' treated with the Ri fungus exhibited the highest GB content when irrigated by the 21-day II. Second to the highest, the treating of 'J-r' with the Fm fungus by the 21-day II also caused a high GB content. However, the lowest content was observed when the ' $\mathrm{H}-\mathrm{d}$ ' was treated with no fungus by the 21 and 14-day IIs (Table 5). 
Table 5. Main effect and interaction between different treatments on proline and glycine betaine content $(\mu \mathrm{mol} /$ gr F.W.)

\begin{tabular}{|c|c|c|c|c|c|c|c|c|c|c|c|c|c|c|c|c|}
\hline \multirow{2}{*}{ Cultivars } & \multirow{2}{*}{ Fungi } & \multirow{2}{*}{$\begin{array}{l}\text { Irrigation } \\
\text { intervals }\end{array}$} & \multicolumn{3}{|c|}{ Interactions Pro } & \multicolumn{3}{|c|}{ Interactions GB } & \multirow{2}{*}{$\begin{array}{l}\text { Main } \\
\text { effects }\end{array}$} & \multirow{2}{*}{ TRTs } & \multicolumn{3}{|c|}{ Pro } & \multicolumn{3}{|c|}{ GB } \\
\hline & & & In & Out $1^{\text {st }}$ & Out $2^{\text {nd }}$ & In & Out $1^{\text {st }}$ & Out $2^{\text {nd }}$ & & & In & Out $1^{\text {st }}$ & Out $2^{\text {nd }}$ & In & Out $1^{\text {st }}$ & Out $2^{\text {nd }}$ \\
\hline \multirow{9}{*}{ 'H-d' } & \multirow{3}{*}{ Control } & 7 & $3.27 \mathrm{ef} \dagger$ & 11.271 & $7.27 \mathrm{~g}$ & $1.73 \mathrm{~g}-\mathrm{i}$ & $3.46 \mathrm{hi}$ & $3.60 \mathrm{ij}$ & \multirow{4}{*}{$\stackrel{\stackrel{n}{E}}{\Xi}$} & \multirow{2}{*}{$\mathrm{Hd}$} & \multirow{2}{*}{$9.87 \mathrm{~A}$} & \multirow{2}{*}{$19.95 \mathrm{~B}$} & \multirow{2}{*}{$14.03 \mathrm{~B}$} & \multirow{2}{*}{$2.19 \mathrm{~B}$} & \multirow{2}{*}{$3.72 \mathrm{~B}$} & \multirow{2}{*}{ 3.74B } \\
\hline & & 14 & $3.84 \mathrm{ef}$ & $11.84 \mathrm{j}-1$ & $7.84 \mathrm{~g}$ & $2.97 \mathrm{bc}$ & $3.44 \mathrm{hi}$ & $3.45 \mathrm{j}$ & & & & & & & & \\
\hline & & 21 & $17.75 \mathrm{bc}$ & $25.74 \mathrm{e}$ & $22.07 \mathrm{~cd}$ & $1.72 \mathrm{~g}-\mathrm{i}$ & $3.33 \mathrm{i}$ & $3.42 \mathrm{j}$ & & \multirow{2}{*}{$\mathrm{Jr}$} & \multirow{2}{*}{$8.73 \mathrm{~A}$} & \multirow{2}{*}{$22.70 \mathrm{~A}$} & \multirow{2}{*}{$18.98 \mathrm{~A}$} & \multirow{2}{*}{$2.72 \mathrm{~A}$} & \multirow{2}{*}{$4.06 \mathrm{~A}$} & \multirow{2}{*}{$4.12 \mathrm{~A}$} \\
\hline & \multirow{3}{*}{$\begin{array}{c}\text { Rhizophagus } \\
\text { irregularis }\end{array}$} & 7 & $4.64 \mathrm{ef}$ & $12.87 \mathrm{~h}-1$ & $7.52 \mathrm{~g}$ & $2.08 \mathrm{fg}$ & $3.58 \mathrm{~g}-\mathrm{i}$ & $3.64 \mathrm{~h}-\mathrm{j}$ & & & & & & & & \\
\hline & & 14 & $6.28 \mathrm{e}$ & $15.61 \mathrm{gh}$ & $10.61 \mathrm{fg}$ & $2.25 \mathrm{~d}-\mathrm{f}$ & $3.81 \mathrm{e}-\mathrm{g}$ & $3.85 \mathrm{f}-\mathrm{i}$ & \multirow{8}{*}{$\stackrel{\text { 总 }}{\Xi}$} & \multirow{3}{*}{ CTL } & & & & & & \\
\hline & & 21 & $20.41 \mathrm{~b}$ & $33.07 \mathrm{c}$ & $18.86 \mathrm{~d}$ & $2.16 \mathrm{ef}$ & $4.28 \mathrm{a}-\mathrm{c}$ & $4.28 \mathrm{bc}$ & & & \multirow{2}{*}{$9.11 \mathrm{~A}$} & $17,30 \%$ & 12360 & סרכר ב & 620 & $265 C$ \\
\hline & \multirow{3}{*}{$\begin{array}{c}\text { Funneliformis } \\
\text { mosseae }\end{array}$} & 7 & $5.75 \mathrm{ef}$ & $12.25 \mathrm{i}-1$ & $9.25 \mathrm{fg}$ & $2.22 \mathrm{~d}-\mathrm{f}$ & $3.93 \mathrm{~d}-\mathrm{f}$ & $3.79 \mathrm{f}-\mathrm{i}$ & & & & 17.09 & 15.100 & $2.22 \mathrm{D}$ & $5,02 \mathrm{D}$ & $3.0 \pi$ \\
\hline & & 14 & $13.39 \mathrm{~d}$ & $20.06 \mathrm{f}$ & $14.99 \mathrm{e}$ & $2.63 \mathrm{~cd}$ & $4.04 \mathrm{~b}-\mathrm{e}$ & $4.02 \mathrm{~d}-\mathrm{f}$ & & $\mathrm{Ri}$ & $960 \mathrm{~A}$ & $21.14 \mathrm{~B}$ & $1558 \mathrm{~B}$ & $257 \mathrm{~A}$ & $409 \mathrm{~A}$ & 4184 \\
\hline & & 21 & $13.48 \mathrm{~d}$ & $36.81 \mathrm{~b}$ & $27.81 \mathrm{~b}$ & $1.98 \mathrm{f}-\mathrm{h}$ & $3.61 \mathrm{~g}-\mathrm{i}$ & $3.63 \mathrm{~h}-\mathrm{j}$ & & & & & & & & \\
\hline & & 7 & $2.38 \mathrm{f}$ & $11.38 \mathrm{kl}$ & $9.04 \mathrm{fg}$ & $1.66 \mathrm{hi}$ & $3.83 \mathrm{e}-\mathrm{g}$ & $3.78 \mathrm{f}-\mathrm{i}$ & & Fm & $9.20 \mathrm{~A}$ & $25.45 \mathrm{~A}$ & $20.77 \mathrm{~A}$ & $2.57 \mathrm{~A}$ & $3.97 \mathrm{~A}$ & $3.96 \mathrm{~B}$ \\
\hline & Control & 14 & $2.76 \mathrm{ef}$ & $14.43 \mathrm{~g}-\mathrm{k}$ & $10.43 \mathrm{fg}$ & $1.98 \mathrm{f}-\mathrm{h}$ & $3.95 \mathrm{~d}-\mathrm{f}$ & $3.93 \mathrm{fg}$ & & & & & & & & \\
\hline & & 21 & $24.66 \mathrm{a}$ & $29.66 \mathrm{~d}$ & $22.32 \mathrm{~cd}$ & $3.28 \mathrm{ab}$ & $3.68 \mathrm{f}-\mathrm{h}$ & $3.73 \mathrm{~g}-\mathrm{i}$ & & & & & & & & \\
\hline & Rhizophagus & 7 & $4.55 \mathrm{ef}$ & $14.88 \mathrm{~g}-\mathrm{j}$ & $12.23 \mathrm{ef}$ & $2.56 \mathrm{c}-\mathrm{e}$ & $4.29 \mathrm{ab}$ & $4.27 \mathrm{~b}-\mathrm{d}$ & & 7 & $3.89 \mathrm{C}$ & $12.96 \mathrm{C}$ & $9.63 \mathrm{C}$ & $1.95 \mathrm{~B}$ & $3.82 \mathrm{~B}$ & $3.82 \mathrm{~B}$ \\
\hline 'J-r' & & 14 & $3.24 \mathrm{ef}$ & $16.91 \mathrm{~g}$ & $14.57 \mathrm{e}$ & $2.70 \mathrm{c}$ & $4.17 \mathrm{a}-\mathrm{d}$ & $4.23 \mathrm{c}-\mathrm{e}$ & & & & & & & & \\
\hline & & 21 & $18.47 \mathrm{bc}$ & $33.47 \mathrm{c}$ & $29.67 \mathrm{~b}$ & $3.68 \mathrm{a}$ & $4.38 \mathrm{a}$ & $4.78 \mathrm{a}$ & है & 14 & $565 \mathrm{~B}$ & $1777 \mathrm{~B}$ & $13.75 \mathrm{~B}$ & 2674 & $3.97 \mathrm{~A}$ & $4.00 \mathrm{~A}$ \\
\hline & Funneliformis & 7 & $2.78 \mathrm{ef}$ & $15.11 \mathrm{~g}-\mathrm{i}$ & $12.45 \mathrm{ef}$ & $1.44 \mathrm{i}$ & $3.81 \mathrm{e}-\mathrm{g}$ & $3.87 \mathrm{f}-\mathrm{h}$ & $\stackrel{.0}{\Xi}$ & & & & & & & \\
\hline & mosseae & 14 & $4.41 \mathrm{ef}$ & $27.74 \mathrm{de}$ & $24.07 \mathrm{c}$ & $3.52 \mathrm{a}$ & $4.43 \mathrm{a}$ & $4.49 \mathrm{~b}$ & & 21 & $18.35 \mathrm{~A}$ & $33.24 \mathrm{~A}$ & $26.13 \mathrm{~A}$ & $2.74 \mathrm{~A}$ & $3.88 \mathrm{AB}$ & $3.97 \mathrm{~A}$ \\
\hline & & 21 & $15.37 \mathrm{~cd}$ & $40.70 \mathrm{a}$ & $36.04 \mathrm{a}$ & $3.63 \mathrm{a}$ & $3.97 \mathrm{c}-\mathrm{f}$ & $3.98 \mathrm{e}-\mathrm{g}$ & & & & & & & & \\
\hline
\end{tabular}

$\dagger$ Means having different letters (capitals for the main effects and lower cases for interactions) are significantly different at $5 \%$ level by LSD test.

* (Pro): proline; (GB): glycine betaine; (In): greenhouse condition; (Out 1 ${ }^{\text {st }}$ ): field environment in the 1st year; (Out $2^{\text {nd }}$ ): field environment in the $2^{\text {nd }}$ year; (TRTs): treatments; (CTL): control; (Ri): Rhizophagus irregularis; (Fm): Funneliformis mosseae.

\subsection{Superoxide dismutase}

There was no significant difference between the two cultivars of Festuca cultivated in the greenhouse. The highest SOD activity was observed in the Fm fungal treatments. The lowest SOD activity was obtained via the Ri fungal treatment which had no significant difference with the control. The 21 and 7-day IIs had the highest and the lowest SOD activities, respectively. Interaction between treatments showed that ' $\mathrm{H}-\mathrm{d}$ ', Fm, 21-day II treatment had the highest SOD activity and 'H-d', the control and 7-day II had the lowest SOD activity in the greenhouse environment.

The 'J-r' had the highest SOD activity in both years in the field experiment. In the first year, the highest
SOD activity was observed in Ri treatment. There was no significant difference between the control and the Fm but, in the second year under field condition, the $\mathrm{Ri}$ had the highest SOD activity, whereas the lowest SOD activity was observed in the control treatment. The highest SOD activity in both years was observed in the 14-day II. However, the SOD activity decreased as a result of the 21-day II. In the second year, the SOD activity in the 21-day treatment was lower than in the 7-day II. In the first year, the highest SOD activity pertained to the interaction between 'J-r', Ri and the 21-day II treatment. In the second year, it was in 'J-r', Ri, 14- and 7-day IIs. The lowest SOD activity was observed in 'H-d', control, 21-day II (Table 6). 
Table 6. Main effect and interaction between different treatments on superoxide dismutase and peroxidase activity (u/g F.W.)

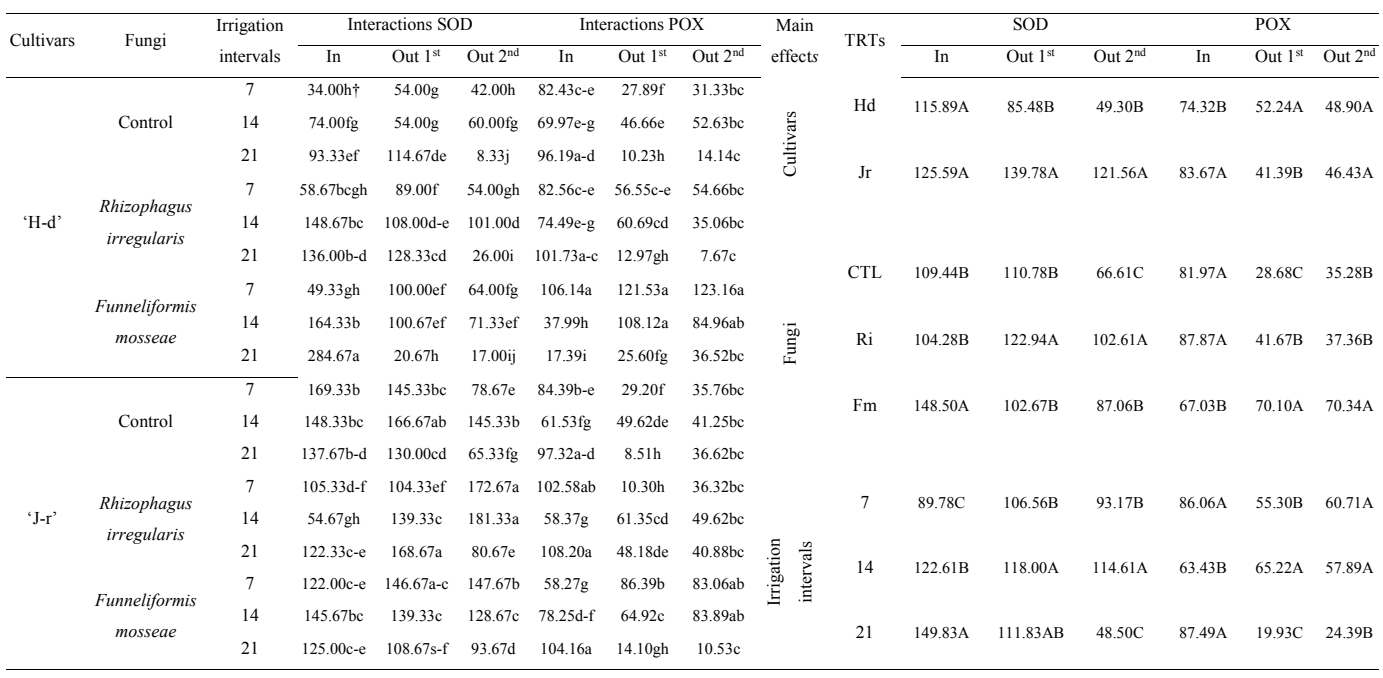

$\dagger$ Means having different letters (capitals for the main effects and lower cases for interactions) are significantly different at $5 \%$ level by LSD test. * (SOD): superoxide dismutase; (POX): peroxidase activity; (In): greenhouse condition; (Out $1^{\text {st) }}$ : field environment in the $1^{\text {st }}$ year; (Out $2^{\text {nd }}$ ): field environment in the $2^{\text {nd }}$ year; (TRTs): treatments; (CTL): control; (Ri): Rhizophagus irregularis; (Fm): Funneliformis mosseae.

\subsection{Peroxidase}

Results showed that the POX decreased initially by the 14-day II, but the highest activity was observed in the 21-day II in the greenhouse experiment. Furthermore, 'J-r' had the highest SOD activity, while Ri and Fm had the highest and the lowest POX activity. Interaction between treatments showed that the highest POX activity was in 'J-r', both fungi treatments, 21-day II and also in 'H-d', Fm, 7-day II, concerning the greenhouse environment.
However, unlike the greenhouse, the field environment showed that ' $\mathrm{H}-\mathrm{d}$ ' had the highest POX activity. Furthermore, the Fm among other treatments caused the highest POX activity. In the first year, the POX activity increased in 14-day II but decreased in 21-day II. In the second year, the POX activity increased as the II increased. The highest POX activity was observed in the interactions of ' $\mathrm{H}-\mathrm{d}$ ', Fm, 7- and 14-day IIs, whereas the lowest activity was observed in both cultivars, control, and the 21-day II (Table 6). 


\subsection{Phosphorus}

The 'J-r' had the highest $\mathrm{P}$ content in the greenhouse. Fungi accounted for most of the P uptakes, while the lowest $\mathrm{P}$ content was observed in the control plants. The content decreased as the II increased. The interaction between 'J-r', Fm and 7-day II showed the highest $\mathrm{P}$ content, but the lowest content was observed in the interaction between ' $\mathrm{H}-\mathrm{d}$ ', the control and the 21day II, in the greenhouse environment. The 'J-r' also exhibited the highest $\mathrm{P}$ content under field condition in both years. Ri had more effect on P content than others and the highest content was observed in this treatment. In both years, the field drought stress reduced the $\mathrm{P}$ content. The highest content was observed in the interaction between 'J-r', Ri, and 7-day II.
The lowest $\mathrm{P}$ content was observed in the interaction between 'H-d', the control, and the 21-day II (Table 7).

\subsection{Root colonization}

Results showed that, in the greenhouse, the 'J-r' exhibits more $\mathrm{RC}$ of fungi in comparison with the 'H-d'. Furthermore, both fungal treatments were observed to increase the magnitude of colonization. On the other hand, RC decreased when II increased in the greenhouse.

In both years for the field environment, 'J-r' had more colonization than ' $\mathrm{H}-\mathrm{d}$ '. Fungal treatments augmented RC significantly, and the control had the lowest $\mathrm{RC}$. Like the greenhouse, $\mathrm{RC}$ in the field environment decreased by increasing the II (Table 7).

Table 7. Main effects and interactions between different treatments on phosphorus concentration (mg/ kg D.W.) and root colonization $(\%)$

\begin{tabular}{|c|c|c|c|c|c|c|c|c|c|c|c|c|c|c|c|c|}
\hline \multirow{2}{*}{ Cultivars } & \multirow{2}{*}{ Fungi } & \multirow{2}{*}{$\begin{array}{l}\text { Irrigation } \\
\text { intervals }\end{array}$} & \multicolumn{3}{|c|}{ Interactions $\mathrm{P}$} & \multicolumn{3}{|c|}{ Interactions RC } & \multirow{2}{*}{ Main effects } & \multirow{2}{*}{ TRTs } & \multicolumn{3}{|c|}{$\mathrm{P}$} & \multicolumn{3}{|c|}{$\mathrm{RC}$} \\
\hline & & & In & Out $1^{\text {st }}$ & Out $2^{\text {nd }}$ & In & Out $1^{\text {st }}$ & Out $2^{\text {nd }}$ & & & In & Out $1^{\text {st }}$ & Out $2^{\text {nd }}$ & In & Out $1^{\text {st }}$ & Out $2^{\text {nd }}$ \\
\hline \multirow{9}{*}{ 'H-d' } & \multirow{3}{*}{ Control } & 7 & $2.24 \mathrm{e}-\mathrm{g} \dagger$ & $2.24 \mathrm{c}$ & $2.22 \mathrm{~b}-\mathrm{e}$ & $32.08 \mathrm{~g}-\mathrm{i}$ & $13.91 \mathrm{f}$ & $9.16 \mathrm{~g}$ & \multirow{5}{*}{ 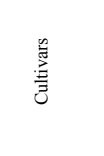 } & $\mathrm{Hd}$ & $266 \mathrm{P}$ & $206 \mathrm{~B}$ & $208 \mathrm{P}$ & $4388 \mathrm{~B}$ & 23078 & 2138 \\
\hline & & 14 & $2.12 \mathrm{fg}$ & $1.62 \mathrm{ef}$ & $1.59 \mathrm{~h}$ & $23.75 \mathrm{ij}$ & $8.41 \mathrm{fg}$ & $4.16 \mathrm{hi}$ & & กव & $2.00 \mathrm{~B}$ & $2.00 \mathrm{~B}$ & $2.08 \mathrm{~B}$ & $43.88 \mathrm{~B}$ & $23.92 \mathrm{~B}$ & $21.33 \mathrm{~B}$ \\
\hline & & 21 & $1.86 \mathrm{~g}$ & $1.53 \mathrm{f}$ & $1.57 \mathrm{~h}$ & $19.58 \mathrm{j}$ & $2.08 \mathrm{~g}$ & $1.83 \mathrm{i}$ & & $\mathrm{Jr}$ & 3044 & 2284 & $227 \mathrm{~A}$ & 47134 & 30394 & 28.384 \\
\hline & \multirow{3}{*}{$\begin{array}{c}\text { Rhizophagus } \\
\text { irregularis }\end{array}$} & 7 & $3.69 \mathrm{ab}$ & $2.32 \mathrm{bc}$ & $2.88 \mathrm{a}$ & $63.33 \mathrm{bc}$ & $45.16 \mathrm{bc}$ & $37.58 \mathrm{c}$ & & & & & & & & \\
\hline & & 14 & $2.51 \mathrm{~d}-\mathrm{f}$ & $2.32 \mathrm{bc}$ & $2.00 \mathrm{e}-\mathrm{g}$ & $55.00 \mathrm{~cd}$ & $26.25 \mathrm{de}$ & $32.06 \mathrm{~d}$ & & & & & & & & \\
\hline & & 21 & $2.41 \mathrm{~d}-\mathrm{f}$ & $2.05 \mathrm{~cd}$ & $2.12 \mathrm{c}-\mathrm{f}$ & $40.41 \mathrm{fg}$ & $22.91 \mathrm{e}$ & $21.83 \mathrm{f}$ & \multirow{7}{*}{ 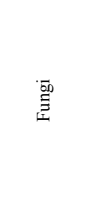 } & \multirow{2}{*}{ CTL } & \multirow{2}{*}{$2.32 \mathrm{~B}$} & \multirow{2}{*}{$1.91 \mathrm{C}$} & \multirow{2}{*}{$1.92 \mathrm{C}$} & \multirow{2}{*}{$27.91 \mathrm{~B}$} & \multirow{2}{*}{$8.04 \mathrm{~B}$} & \multirow{2}{*}{$5.16 \mathrm{~B}$} \\
\hline & \multirow{3}{*}{$\begin{array}{c}\text { Funneliformis } \\
\text { mosseae }\end{array}$} & 7 & $3.70 \mathrm{ab}$ & $2.54 \mathrm{~b}$ & $2.44 \mathrm{~b}$ & $75.83 \mathrm{a}$ & $39.25 \mathrm{c}$ & $40.83 \mathrm{c}$ & & & & & & & & \\
\hline & & 14 & $2.88 \mathrm{~cd}$ & $2.29 \mathrm{bc}$ & $2.30 \mathrm{~b}-\mathrm{d}$ & $46.66 \mathrm{~d}-\mathrm{f}$ & $28.58 \mathrm{de}$ & $26.51 \mathrm{e}$ & & \multirow{2}{*}{$\mathrm{Ri}$} & \multirow{2}{*}{$3.02 \mathrm{~A}$} & \multirow{2}{*}{$2.36 \mathrm{~A}$} & \multirow{2}{*}{$2.42 \mathrm{~A}$} & \multirow{2}{*}{$54.30 \mathrm{~A}$} & \multirow{2}{*}{$37.00 \mathrm{~A}$} & \multirow{2}{*}{$34.19 \mathrm{~A}$} \\
\hline & & 21 & $2.51 \mathrm{~d}-\mathrm{f}$ & $1.60 \mathrm{ef}$ & $1.58 \mathrm{~h}$ & $38.33 \mathrm{f}-\mathrm{h}$ & $28.75 \mathrm{de}$ & $19.00 \mathrm{f}$ & & & & & & & & \\
\hline \multirow{9}{*}{ 'J-r' } & \multirow{3}{*}{ Control } & 7 & $2.71 \mathrm{de}$ & $2.28 \mathrm{bc}$ & $2.31 \mathrm{~b}-\mathrm{d}$ & $38.33 \mathrm{f}-\mathrm{h}$ & $8.41 \mathrm{fg}$ & $6.83 \mathrm{gh}$ & & $\mathrm{Fm}$ & $3.20 \mathrm{~A}$ & $2.23 \mathrm{~B}$ & $2.18 \mathrm{~B}$ & $54.30 \mathrm{~A}$ & $36.44 \mathrm{~A}$ & $35.21 \mathrm{~A}$ \\
\hline & & 14 & $2.79 \mathrm{~d}$ & $2.05 \mathrm{~cd}$ & $2.07 \mathrm{~d}-\mathrm{f}$ & $30.00 \mathrm{hi}$ & $12.08 \mathrm{f}$ & $6.66 \mathrm{gh}$ & & & & & & & & \\
\hline & & 21 & $2.22 \mathrm{e}-\mathrm{g}$ & $1.75 \mathrm{ef}$ & $1.75 \mathrm{gh}$ & $23.75 \mathrm{ij}$ & $3.33 \mathrm{~g}$ & 3.33hi & & & & & & & & \\
\hline & & 7 & $3.48 \mathrm{~b}$ & $3.12 \mathrm{a}$ & $3.17 \mathrm{a}$ & $69.58 \mathrm{ab}$ & $53.16 \mathrm{a}$ & $55.25 \mathrm{a}$ & & 7 & 3331 & 2564 & 2574 & 58814 & 34704 & 33584 \\
\hline & Knizopnagus & 14 & $3.46 \mathrm{~b}$ & $2.57 \mathrm{~b}$ & $2.49 \mathrm{~b}$ & $52.91 \mathrm{de}$ & $47.91 \mathrm{ab}$ & $37.75 \mathrm{c}$ & & 1 & $3.33 \mathrm{~A}$ & $2.56 \mathrm{~A}$ & $2.5 / \mathrm{A}$ & $38.81 \mathrm{~A}$ & $34.70 \mathrm{~A}$ & $33.58 \mathrm{~A}$ \\
\hline & trregularts & 21 & $2.56 \mathrm{~d}-\mathrm{f}$ & $1.79 \mathrm{~d}-\mathrm{f}$ & $1.88 \mathrm{fg}$ & $44.58 \mathrm{ef}$ & $26.58 \mathrm{de}$ & $20.83 \mathrm{f}$ & 总 & 14 & $2.86 \mathrm{~B}$ & $2.12 \mathrm{~B}$ & $2.15 \mathrm{~B}$ & $43.54 \mathrm{~B}$ & $27.69 \mathrm{~B}$ & $25.50 \mathrm{~B}$ \\
\hline & Funneliformis & 7 & $4.18 \mathrm{a}$ & $2.88 \mathrm{a}$ & $2.41 \mathrm{bc}$ & $73.75 \mathrm{a}$ & $48.33 \mathrm{ab}$ & $51.83 \mathrm{a}$ & 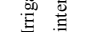 & & & & & & & \\
\hline & mosseae & 14 & $3.39 \mathrm{bc}$ & $1.88 \mathrm{de}$ & $2.47 \mathrm{~b}$ & $52.91 \mathrm{de}$ & $42.91 \mathrm{bc}$ & $45.83 \mathrm{~b}$ & & 21 & $2.35 \mathrm{C}$ & $1.82 \mathrm{C}$ & $1.80 \mathrm{C}$ & $34.16 \mathrm{C}$ & $19.08 \mathrm{C}$ & $15.48 \mathrm{C}$ \\
\hline & & 21 & $2.55 \mathrm{~d}-\mathrm{f}$ & $2.18 \mathrm{c}$ & $1.91 \mathrm{fg}$ & $38.33 \mathrm{f}-\mathrm{h}$ & $30.83 \mathrm{~d}$ & $27.08 \mathrm{e}$ & & & & & & & & \\
\hline
\end{tabular}

$\uparrow$ Means having different letters (capitals for the main effects and lower cases for interactions) are significantly different at $5 \%$ level by LSD test.

* (P): phosphorus; (RC): root colonization; (In): greenhouse condition; (Out $\left.1^{\text {st }}\right)$ : field environment in the $1^{\text {st }}$ year; $\left(\right.$ Out $\left.2^{\text {nd }}\right)$ : field environment in the $2^{\text {nd }}$ year; (TRTs): treatments; (CTL): control; (Ri): Rhizophagus irregularis; (Fm): Funneliformis mosseae. 


\subsection{Recovery period}

The best recovery was achieved in the AMFs treatment, whereas the control displayed no improvements (Figure 1).
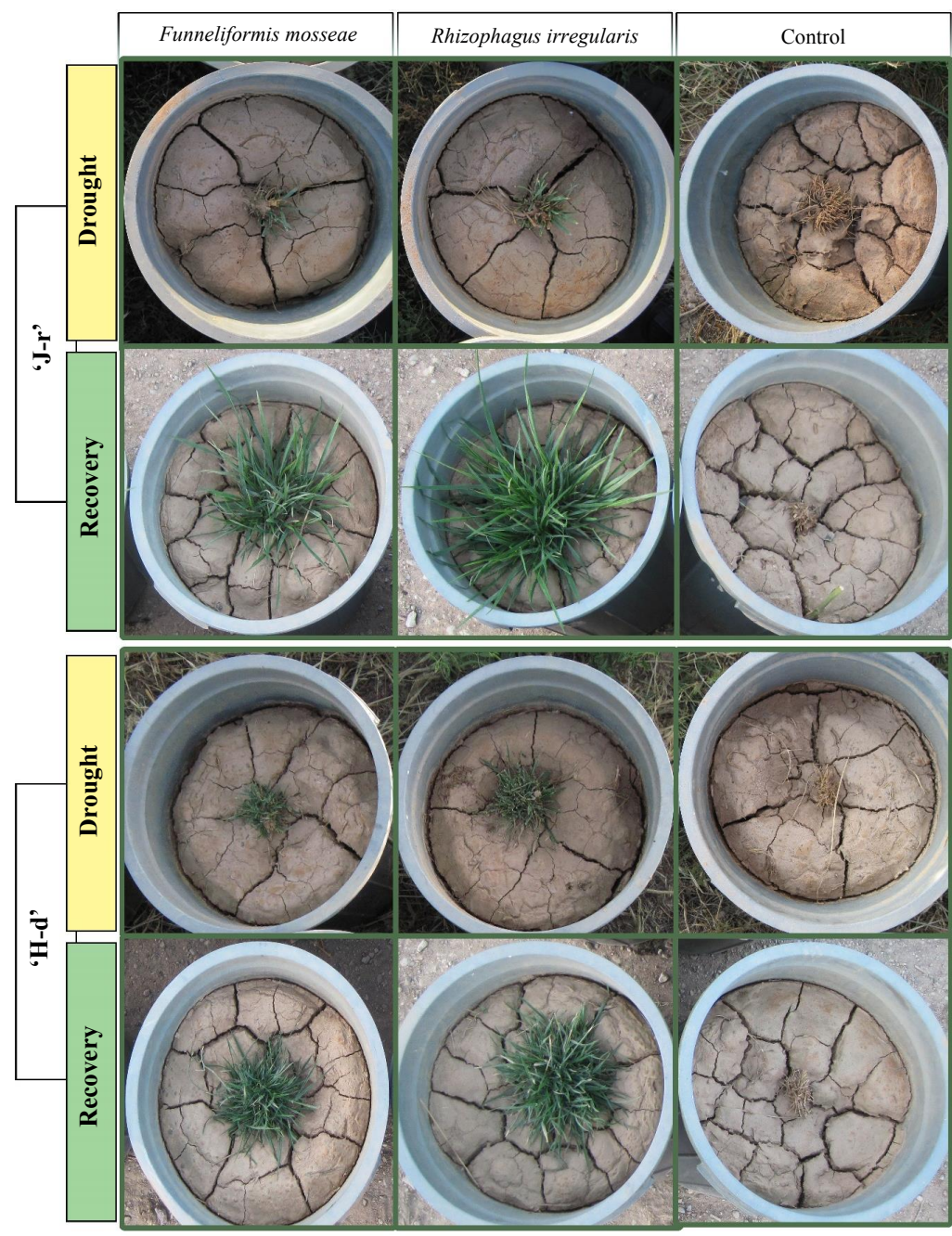

Figure 1. Analogy visual quality of two cultivars of tall fescue between fungi treatments and control at recovery period and severe drought stress. 


\section{Discussion}

Perceptibly, decrease in plant quality i.e. turfgrass FW and RWC can resulted from the reduction in cell turgor pressure under drought stress. The decrease in osmotic pressure causes plant cells to shrink due to tissue water loss and it can culminate in plant weakness (Taiz et al., 2015). In this experiment, reductions in VQ, RWC and total FW were observed as the II increased. This reduction was less pronounced in the greenhouse than the field environment. Although the approximate quality features of ' $\mathrm{H}-\mathrm{d}$ ' was acceptable under the greenhouse condition, 'J-r' showed better function in general. Many research projects have focused on the effects of drought stress on the tall fescue (Caturegli et al., 2015; Ebrahimiyan et al., 2013; Etemadi et al., 2015; Fu and Huang, 2001; Jiang and Huang, 2001; Manuchehri and Salehi, 2015; Pirnajmedin et al., 2015; Sarmast et al., 2015). It has been reported that shortage in the water supply reduces VQ, RWC and FW. Man et al. (2011) reported that the reduction in VQ and RWC - as a result of drought stress in tall fescue - is reversible in the recovery period. According to this research, the VQ, FW and RWC rendered better results when plants were treated with AMFs during the recovery period. Researchers have shown that AMFs improve plant-water relations and that the morphological conditions of the plant are enhanced by their roots. This enhancement can also be explained by the secretion of glomalin that contributes to a better uptake of water and nutrients by the plant (Cornejo et al., 2017; Durán et al., 2016; Miransari, 2014; Quiñones-Aguilar et al., 2016).

Leaf $\mathrm{Chl}$ content is one of the most important physiological characters that can change during stressful conditions. In fact, Chl content decreases as a result of accelerating lipid peroxidation and the demolition of chloroplast membranes (Fracheboud and Leipner, 2003). Many reports show that drought stress can sub- stantially reduce the Chl content in the tall fescue, but in some cases the pattern of reduction could display an inconsistent trend, depending on environmental conditions, soil type and genetic traits of the cultivar. These may have sudden incremental effects on the Chl content or sometimes erratic changes in the initial period of stress or mild stress. Then, as the stress continues to persist, the $\mathrm{Chl}$ content will decrease subsequently (Ebrahimiyan et al., 2013; Etemadi et al., 2015; Fu and Huang, 2001; Jiang and Huang, 2001; Manuchehri and Salehi, 2015; Pirnajmedin et al., 2015; Sarmast et al., 2015). The results of this study indicate that less frequencies of irrigation can cause reductions in the $\mathrm{Chl}$ and generally ' $\mathrm{H}-\mathrm{d}$ ' indicates better function than 'J-r' especially under the greenhouse condition, but when plants were treated with AMFs, the lower irrigation frequency was less detrimental in comparison to the control. AMFs increase the $\mathrm{Chl}$ concentration in the plant by enhancing the plant's $\mathrm{N}$ and $\mathrm{Mg}$ uptake, as these are inseparable components of the chlorophyll molecule (Miransari, 2014). Furthermore, the AMFs serve to increase the surface area between the roots and the soil. In this respect, they increase the leaf water potential and antioxidant enzyme activity in a manner that leads to the $\mathrm{Chl}$ being less damaged under stressful conditions (Augé, 2001, 2004; Durán et al., 2016).

GB and Pro are the main organic osmolytes that accumulate in response to environmental stresses in plants. They regulate the osmotic pressure and also maintain the redox balance by regulating $\mathrm{Mg}$ and ROS metabolism (Chen and Murata, 2008; Szabados and Savoure, 2010). Different studies have investigated the effects of drought stress on the tolerance of tall fescue cultivars. Reports indicate that the Pro content increased in plants in response to drought (Ebrahimiyan et al., 2013; Etemadi et al., 2015; Man et al., 2011; Manuchehri and Salehi, 2015; Pirnajmedin et al., 2015; Sarmast et al., 2015). According to previous 
evidence and this experiment, the tall fescue may be introduced as a specific model plant for its increase in Pro content when being exposed to drought stress. In this experiment, the GB concentration increased under drought stress. Our results confirm a few studies on monocotyledons such as the report concerning Corn (Quan et al., 2004). In the present study, the increase in amino acids content was observed parallel to the increase of II. The 'J-r' as drought-tolerant cultivar had higher levels of amino acid content than 'H-d'; AMFs treatments showed the same compared to the control, especially under field condition as a result of severe stresses. There is no report about AMFs mechanism in osmolytes, however some reports indicate positive relations between these microorganisms and the amount of amino acids against abiotic stresses (Pinior et al., 2005).

Researches show that stresses such as water deficiency can lead to cellular damage by ROS activation. The SOD accelerates $\mathrm{O}_{2} \bullet$ - conversion to $\mathrm{H}_{2} \mathrm{O}_{2}$ and $\mathrm{O}_{2}$ in plants which are exposed to abiotic stress. The POX improves plant growth under stressful conditions by oxidizing various substrates using $\mathrm{H}_{2} \mathrm{O}_{2}$ and by preventing the excess accumulation of $\mathrm{H}_{2} \mathrm{O}_{2}$ (Karuppanapandian et al., 2011). Many studies about the tall fescue showed that the SOD and POX enzymes activity increase in stress conditions. However, in some cases, enzyme-disorder activity was observed along with the decrease or erratic decrease-increase in enzyme activity due to the severity of stress and the special features of the cultivar in coping with stress (Etemadi et al., 2015; Fu and Huang, 2001; Jiang and Huang, 2001; Manuchehri and Salehi, 2015; Pirnajmedin et al., 2015; Sarmast et al., 2015). In this study, the 'J-r' with fungal treatments had optimum enzymatic performance against stress, except for POX in the greenhouse condition. Most fungal treatments and for most of the IIs, either the greenhouse or the field condition increased enzymatic activity, but in some cases the Fm could not change the POX activity in the greenhouse in comparison with the control. Altogether, most treatments led to the increase in enzymatic activity parallel to the increase in II, but we found instances of decrease-increase and erratic changes in enzymatic activity. This erratic change is in agreement with previous studies. It seems that mycorrhizal colonization and the arbuscule have important roles in $\mathrm{O}_{2} \bullet$ - reduction and facilitate the degradation of $\mathrm{H}_{2} \mathrm{O}_{2}$ in the plant against abiotic stresses. Plant symbiosis with AMFs in the short-run can increase enzyme activity and induce enzyme genes and new isoforms (Durán et al., 2016; Wu et al., 2014).

Phosphorus is an essential macroelement for the plant and plays crucial roles in some main cell functions in the plant such as sugar-phosphate intermediate of respiration and photosynthesis and phospholipids that make up the plant membrane. Under stress conditions, the P content and uptake decrease and lead to a less vigorous growth, narrow shoot production, leaf senescence and leaf firing. In this experiment, the P content decreased as the II increased, which is in agreement with a previous report by Huang (2001). Moreover, this reduction was lesser in 'J-r' compared to 'H-d' and occurred less in AMFs treatments, as well, especially when treated by Ri. The main role of AMFs is to make available the inactive macroelements in the soil to the plant. The uptake of $\mathrm{P}$ is improved by AMFs under stress because of the integrity maintenance of vacuolar membranes and different enzymes production such as phosphatase (Smith and Read, 2008; Miransari, 2014).

Researchers have shown that by increasing the RC, the total surface area covered by the fungus increases as well (including root length, root architecture, and root/shoot ratio) which prompts the improvement in relations of nutrient acquisition and hydration. Many studies have shown that RC could decrease in response to the scarcity of moisture in the soil, however 
the percentage of RC may differ based on the soil type and plant or fungi species (Augé, 2001, 2004; Grümberg et al., 2015; Wu et al., 2013). In this study, the RC percentage decreased with increasing the II while in general, this reduction was lesser in ' $J-r$ ' compared to ' $\mathrm{H}-\mathrm{d}$ '. According to the results, there is a direct relationship between plant growth and RC. Under stress conditions, plant growth decreases. However, by increasing the $\mathrm{RC}$, the plant growth increases relatively in comparison with the control. Due to controlled condition in the greenhouse, especially in terms of moisture, turfgrasses which were in the greenhouse had higher levels of growth and RC than the field-grown ones.

\section{Conclusions}

Management against drought stress requires novel approaches of which the AMFs can generate promising results. Turfgrass is commonly replaced with other drought-tolerant plants in places where the water consumption of turfgrass is deemed too excessive. The question remains whether any solutions exist to reduce turfgrass water requirement so as to prevent the turfgrass from being replaced with other plants. This study was the first extensive research that investigated plant biomass, the amino acid and antioxidant enzymes activity on a quantitative and qualitative basis, in the light of turfgrass treatment with AMFs. Characteristics of the tall fescue can be improved as a result of its interaction with AMFs - besides monitoring water relationship by applying different IIs. Our results proved that 'J-r' and 7-day II with Fm treatment is the best in terms of inducing plant tolerance against drought. In regions where limitations to water resources are prevalent, the 14-day II could also yield acceptable quality in the tall fescue. This research concluded that AMFs can save vital organs of the tall fescue, especially the crown, when being under severe and long stressful conditions. As a matter of consequence, then, most of the organs can be revived in the recovery period. Where drought stress is problematic, this research recommends the turfgrass be inoculated with AMFs during the rainy season in order to increase turfgrass compatibility and to strengthen RC. This research can provide a methodological template for more studies on other species of turfgrass, since turfgrass have seldom been treated with AMFs.

\section{References}

Augé, R.M. 2001. Water relations, drought and vesicular-arbuscular mycorrhizal symbiosis. Mycorrhiza. 11, 3-42.

Augé, R.M. 2004. Arbuscular mycorrhizae and soil/ plant water relations. Can. J. Soil Sci. 84, 373381.

Bates, L.S., Waldren, R.P., Teare, I.D. 1973. Rapid determination of free proline for water-stress studies. Plant Soil. 39, 205-207.

Beauchamp, C., Fridovich, I. 1971. Superoxide dismutase: improved assays and an assay applicable to acrylamide gels. Anal. Biochem. 44, 276-287.

Caturegli, L., Grossi, N., Saltari, M., Gaetani, M., Magni, S., Nikolopoulou, A.E., Bonari, E., Volterrani, M. 2015. Spectral reflectance of tall fescue (Festuca arundinacea Schreb.) under different irrigation and nitrogen conditions. Agric. Agric. Sci. Procedia. 4, 59-67.

Chance, B., Maehly, A.C. 1955. Assay of catalases and peroxidases. In: S.P. Colowick, N.O. Kaplan (eds.), Methods in enzymology. Academic Press, New York, pp: 764-775.

Chen, T.H.H., Murata, N. 2008. Glycinebetaine: an effective protectant against abiotic stress in plants. Trends Plant Sci. 13, 499-505. 
Cornejo, P., Meier, S., García, S., Ferrol, N., Durán, P., Borie, F., Seguel, A. 2017. Contribution of inoculation with arbuscular mycorrhizal fungi to the bioremediation of a copper contaminated soil using Oenothera picensis. J. Soil Sci. Plant Nutr. 17, 14-21.

Durán, P., Acuña, J.J., Armada, E., López-Castillo, O.M., Cornejo, P., Mora, M.L., Azcón, R. 2016. Inoculation with selenobacteria and arbuscular mycorrhizal fungi to enhance selenium content in lettuce plants and improve tolerance against drought stress. J. Soil Sci. Plant Nutr. 16, 211-225.

Ebrahimiyan, M., Majidi, M.M., Mirlohi, A., Noroozi, A. 2013. Physiological traits related to drought tolerance in tall fescue. Euphytica. 190, 401-414.

Esmaili, S., Salehi, H. 2012. Effects of temperature and photoperiod on postponing bermudagrass (Cynodon dactylon [L.] Pers.) turf dormancy. J. Plant Physiol. 169, 851-858.

Etemadi, N., Sheikh-Mohammadi, M.H., Nikbakht, A., Sabzalian, M.R., Pessarakli, M. 2015. Influence of trinexapac-ethyl in improving drought resistance of wheatgrass and tall fescue. Acta Physiol. Plant. 37, 1-17.

Fracheboud, Y., Leipner, J. 2003. The application of chlorophyll fluorescence to study light, temperature, and drought stress. In: J.R. DeEll, P.M.A. Toivonen (eds), Practical applications of chlorophyll fluorescence in plant biology. Springer US, Boston, MA, pp: 125-150.

Fry, J., Huang, B. 2004. Applied turfgrass science and physiology. John Wiley and Sons, Inc., Hoboken, NJ.

Fu, J., Huang, B. 2001. Involvement of antioxidants and lipid peroxidation in the adaptation of two cool-season grasses to localized drought stress. Environ. Exp. Bot. 45, 105-114.

Garg, N., Chandel, S. 2010. Arbuscular mycorrhizal networks: process and functions. a review. Agron. Sustainable Dev. 30, 581-599.
González, L., González-Vilar, M. 2001. Determination of relative water content. In: M.J.R. Roger (ed), Handbook of plant ecophysiology techniques. Kluwer Academic Publishers, Dordrecht, 207-212.

Grieve, C.M., Grattan, S.R. 1983. Rapid assay for determination of water soluble quaternary ammonium compounds. Plant Soil. 70, 303-307.

Grümberg, B.C., Urcelay, C., Shroeder, M.A., VargasGil, S., Luna, C.M. 2015. The role of inoculum identity in drought stress mitigation by arbuscular mycorrhizal fungi in soybean. Biol. Fertil. Soils. 51, 1-10.

Huang, B. 2001. Nutrient accumulation and associated root characteristics in response to drought stress in tall fescue cultivars. HortScience. 36, 148-152.

Jeffries, P., Gianinazzi, S., Perotto, S., Turnau, K., Barea, J.M. 2003. The contribution of arbuscular mycorrhizal fungi in sustainable maintenance of plant health and soil fertility. Biol. Fertil. Soils. 37, 1-16.

Jiang, Y., Huang, B., 2001 Drought and heat stress injury to two cool-season turfgrasses in relation to antioxidant metabolism and lipid peroxidation. Crop Sci. 41, 436-442.

Karuppanapandian, T., Moon, J.C., Kim, C., Manoharan, K., Kim, W. 2011. Reactive oxygen species in plants: their generation, signal transduction, and scavenging mechanisms. Aust. J. Crop Sci. 5, 709-725.

Kormanik, P.P., McGraw, A.C. 1982. Quantification of vesicular-arbuscular mycorrhizae in plant roots. In: N.C. Schenck (ed), Methods and principles of mycorrhizal research. APS Press, Saint Paul, Minn, pp: 37-45.

López-Ráez, J.A. 2015. How drought and salinity affect arbuscular mycorrhizal symbiosis and strigolactone biosynthesis? Planta. 1-11. 
Man, D., Bao, Y.X., Han, L.B., Zhang, X. 2011. Drought tolerance associated with proline and hormone metabolism in two tall fescue cultivars. HortScience. 46, 1027-1032.

Manuchehri, R., Salehi, H. 2015. Morphophysiological and biochemical changes in tall fescue (Festuca arundinacea Schreb.) under combined salinity and deficit irrigation stresses. Desert. 20, 29-38.

McCann, S.E., Huang, B. 2007. Turfgrass drought physiology and irrigation management. In: M. Pessarakli (ed), Handbook of turfgrass management and physiology. CRC Press, Boca Raton, FL, pp: 431-445.

Miransari, M. 2014. Use of microbes for the alleviation of soil stresses, Volume 1, 2. Springer-Verlag, New York.

Nikbakht, A., Pessarakli, M. 2014. New approaches to turfgrass nutrition: humic substances and mycorrhizal inoculation. In: M. Pessarakli (ed), Handbook of plant and crop physiology, Third Edition. CRC Press, Boca Raton, pp: 917-929.

Pinior, A., Grunewaldt-Stöcker, G., von Alten, H., Strasser, R.J. 2005. Mycorrhizal impact on drought stress tolerance of rose plants probed by chlorophyll a fluorescence, proline content and visual scoring. Mycorrhiza. 15, 596-605.

Pirnajmedin, F., Majidi, M.M., Gheysari, M. 2015. Root and physiological characteristics associated with drought tolerance in Iranian tall fescue. Euphytica. 202, 141-155.

Pozo, M.J., López-Ráez, J.A., Azcón-Aguilar, C., García-Garrido, J.M. 2015. Phytohormones as integrators of environmental signals in the regulation of mycorrhizal symbioses. New Phytol. 205, 1431-1436.

Quan, R., Shang, M., Zhang, H., Zhao, Y., Zhang, J. 2004. Engineering of enhanced glycine betaine synthesis improves drought tolerance in maize. Plant Biotechnol. J. 2, 477-486.
Quiñones-Aguilar, E.E., Montoya-Martínez, A.C., Rincón-Enriquez, G., Lobit, P., López-Pérez, L. 2016. Effectiveness of native arbuscular mycorrhizal consortia on the growth of Agave inaequidens. J. Soil Sci. Plant Nutr. 16, 1052-1064.

Rai, M.K., 2006. Handbook of microbial biofertilizers. Food Products Press, New York.

Sarmast, M.K., Salehi, H., Niazi, A. 2015. Biochemical differences underlie varying drought tolerance in four Festuca arundinacea Schreb. genotypes subjected to short water scarcity. Acta Physiol. Plant. 37, 1-13.

Smith, S.E., Read, D.J. 2008. Mycorrhizal symbiosis, Third Edition. Academic Press, Amsterdam.

Szabados, L., Savoure, A. 2010. Proline: a multifunctional amino acid. Trends Plant Sci. 15, 89-97.

Taiz, L., Zeiger, E., Møller, I.M., Murphy, A.S. 2015. Plant physiology and development, Sixth Edition. Sinauer Associates, Inc., Sunderland, MA.

Watanabe, F.S., Olsen, S.R. 1965. Test of an ascorbic acid method for determining phosphorus in water and $\mathrm{NaHCO}_{3}$ extracts from soil. Soil Sci. Soc. Am. J. 29, 677-678.

Wu, Q.S., Srivastava, A.K., Zou, Y.N. 2013. AMFinduced tolerance to drought stress in citrus: a review. Sci. Hortic. 164, 77-87.

Wu, Q.S., Zou, Y.N., Abd_Allah, E.F. 2014. Mycorrhizal association and ROS in plants. In: P. Ahmad (ed), Oxidative damage to plants: antioxidant networks and signaling. Acad. Press, Amsterdam, 453-475.

Zarei, M., König, S., Hempel, S., Nekouei, M.K., Savaghebi, Gh., Buscot, F. 2008a. Community structure of arbuscular mycorrhizal fungi associated to $\mathrm{Ve}$ ronica rechingeri at the Anguran zinc and lead mining region. Environ. Pollut. 156, 1277-1283.

Zarei, M., Saleh-Rastin, N., Jouzani, G.S., Savaghebi, G., Buscot, F. 2008b. Arbuscular mycorrhizal abundance in contaminated soils around a zinc and lead deposit. Eur. J. Soil Biol. 44, 381-391 